\title{
The Salão da Bússola (1969) and Do Corpo à Terra (1970): Parallel Developments in Brazilian and International Art
}

\section{Anna Katherine Brodbeck}

Volume 38, numéro 2, 2013

Contemporary Scholarship on Latin American Art

Approches contemporaines de l'art latino-américain

URI : https://id.erudit.org/iderudit/1020797ar

DOI : https://doi.org/10.7202/1020797ar

Aller au sommaire du numéro

\section{Éditeur(s)}

UAAC-AAUC (University Art Association of Canada | Association d'art des universités du Canada)

\section{ISSN}

0315-9906 (imprimé)

1981-4778 (numérique)

Découvrir la revue

Citer cet article

Brodbeck, A. K. (2013). The Salão da Bússola (1969) and Do Corpo à Terra (1970): Parallel Developments in Brazilian and International Art. RACAR : Revue d'art canadienne / Canadian Art Review, 38(2), 109-123.

https://doi.org/10.7202/1020797ar

\section{Résumé de l'article}

Les artistes brésiliens des années 1960 et 1970 se sont profondément investis dans leur propre contribution au modernisme, notamment par rapport aux modèles européens qui avaient fasciné leur milieu culturel dès les années 1920. Répondant à l'appel d'Oswald de Andrade, qui dans son "Manifesto Antropófago" (1928) conseillait aux artistes brésiliens de dévorer les sources matérielles importées afin de créer un art unique à leur pays, les artistes et critiques brésiliens de cette époque tentent de redéfinir leur relation avec l'art moderne international. Cet article examine deux expositions fondamentales. La première, le Salão da Bússola (1969) annonce l'émergence de "l'anti-art », caractérisé par la performance corporelle et l'usage de matériaux « pauvres ». La seconde, Do Corpo à Terra (1970) définit encore plus clairement la réponse brésilienne aux mouvements bourgeonnants de l'art " post-atelier » tels que arte povera, process art, et land art. Les efforts des conservateurs ainsi que la réponse critique envers ces expositions révèlent l'intention délibérée de positionner ces expériences par rapport non seulement aux artistes contemporains tel que Jan Dibbets, mais aussi aux artistes de l'avant-garde historique tels que Kurt Schwitters et Kazimir Malevitch. En réagissant simultanément à l'héritage de l'avant-garde européenne et aux préoccupations locales contemporaines, les artistes brésiliens de cette époque ont effectivement répondu à l'appel d'Andrade en créant un art né au Brésil dans une démarche parallèle à celle de l'art international.
Tous droits réservés (C) UAAC-AAUC (University Art Association of Canada | Association d'art des universités du Canada), 2013
Ce document est protégé par la loi sur le droit d'auteur. L’utilisation des services d'Érudit (y compris la reproduction) est assujettie à sa politique d'utilisation que vous pouvez consulter en ligne.

https://apropos.erudit.org/fr/usagers/politique-dutilisation/ 


\title{
The Salão da Bússola (1969) and Do Corpo à Terra (1970): Parallel Developments in Brazilian and International Art
}

\author{
Anna Katherine Brodbeck, Institute of Fine Arts, New York University
}

\section{Résumé}

Les artistes brésiliens des années 1960 et 1970 se sont profondément investis dans leur propre contribution au modernisme, notamment par rapport aux modèles européens qui avaient fasciné leur milieu culturel dès les années 1920. Répondant à l'appel d'Oswald de Andrade, qui dans son "Manifesto Antropófago" (1928) conseillait aux artistes brésiliens de dévorer les sources matérielles importées afin de créer un art unique à leur pays, les artistes et critiques brésiliens de cette époque tentent de redéfinir leur relation avec l'art moderne international. Cet article examine deux expositions fondamentales. La première, le Salão da Bússola (1969) annonce l'émergence de « l'anti-art », caractérisé par la performance corporelle et l'usage de matériaux « pauvres ». La seconde, Do Corpo à Terra (1970) définit encore plus clairement la réponse brésilienne aux mouvements bourgeonnants de l'art « post-atelier » tels que arte povera, process art, et land art. Les efforts des conservateurs ainsi que la réponse critique envers ces expositions révèlent l'intention délibérée de positionner ces expériences par rapport non seulement aux artistes contemporains tel que Jan Dibbets, mais aussi aux artistes de l'avant-garde historique tels que Kurt Schwitters et Kazimir Malevitch. En réagissant simultanément à l'héritage de l'avant-garde européenne et aux préoccupations locales contemporaines, les artistes brésiliens de cette époque ont effectivement répondu à l'appel d'Andrade en créant un art né au Brésil dans une démarche parallèle à celle de l'art international.

$\mathrm{I}_{\mathrm{n}}$ (From Body to Earth), the people of Belo Horizonte witnessed Cildo Meireles burn live chickens at the stake, Artur Barrio throw burlap sacks filled with raw meat and trash into an open sewer, and Décio Noviello detonate grenades of coloured smoke. Belo Horizonte, the capital of the state of Minas Gerais, was considered provincial by comparison with São Paulo and Rio de Janeiro, the larger metropolitan centres of the Brazilian art world. Unsurprisingly, these violent actions were the cause of significant controversy among state officials; six years earlier a coup d'etat had placed the country under military rule, severely limiting the freedom of expression of its citizens. Defending the artists in question, critic Mari'Stella Tristão, a co-organizer of the exhibition, wrote, "For the first time in the history of the Plastic Arts in Minas, we are walking parallel to national and international movements. We are breaking the taboo that our mountains limit us and close us off." 1

Although such daring actions offended official sensibilities, Brazilian artists had been producing art that paralleled international trends for quite some time. ${ }^{2}$ In 1922, the Semana de Arte Moderna (Week of Modern Art) introduced to São Paulo a modernism conversant with European art. In response, the poet Oswald de Andrade wrote his 1928 "Manifesto Antropófago" ("Anthropophagite Manifesto"), 3 which famously argued that artists in Brazil should aggressively devour imported source material to create something unique to their country. Following in this spirit, theorists of Brazilian culture have long sought to define their own relation to foreign art, often wavering between engagement and avoidance. By mid-century, critics worked in a context in which international modernism was quite prominent: there were now several modern art institutions with strong international ties, most importantly, the São Paulo Biennial, founded in 1951, the second oldest after that of Venice.

In 1970 the artist Hélio Oiticica responded to Andrade with a manifesto of his own, "Brasil Diarréa" ("Brazil Diar- rhea”). ${ }^{4}$ In it he challenged conservative cultural critics' paternalistic embracing of folkloric art and rejection of "universal" tendencies present in foreign art. Instead, Oiticica promoted experimentation above all, effectively updating anthropophagism for a younger generation of artists who opted for "post-studio" (or "anti-art") practices that intersected with arte povera, conceptualism, land art, and process art.5 Oiticica is best known for his contributions to the Neoconcrete movement of the late 1950 s, into which he and colleagues including Lygia Clark injected a geometric abstraction with an organic dynamism that pushed the object into real space. These experiments culminated in participatory experiences and immersive environments that often utilized ready-made and easily accessible materials. Their work greatly impacted younger Brazilian artists, and their legacy would also resonate with the new media work seen in the late 1960s in catalogues for international exhibitions such as Live in Your Head: When Attitudes Become Form that were widely circulated in Brazil. 6 This large-scale exhibition in particular included artists' contributions from New York, Los Angeles, London, Amsterdam, Rome, and the cities of Northern Italy, but also from less expected locations such as Wisconsin and Kerala, India. It was representative of the new mobility afforded by emerging trends, which allowed artists to reconceive artistic production and distribution nomadically.

In spite of Brazil's long history of transnational exchange, a historiographic lacuna emerged in the decades following the 1970s that prevented this generation from gaining proper appreciation abroad. Indeed, narratives forged in North American and European "centres" have long misunderstood or ignored the contributions of Latin American artists. The result, as epitomized by Mari Carmen Ramírez's influential essay "Blueprint Circuits: Conceptual Art and Politics in Latin America," has been that the contributions of Latin American artists have been segregated and extolled on their own rather than incorporated into a larger history. The stark division that Ramírez created 
between Latin American conceptualism, which she characterized as "ideological," and European and North American conceptualism, which she saw as endemically formalist, obfuscated the possibility of any intersection. ${ }^{7}$ This ideological component is often attributed to the dictatorships under which many artists in Latin America have worked, and, as I will suggest, many Brazilian artists did utilize metaphor to allude to the political situation in their country. Yet, a purely segregationist approach obscures significant moments of exchange between the Americas and Europe. ${ }^{8}$ The effects of the conditions of dictatorship on artistic production have been addressed recently in thoughtful detail and thus will not be considered here in depth, ${ }^{9}$ but there is one point at which they are particularly instructive. Many artists responded to the oppressive conditions in their country by looking outward, through strategies explored below; by the same token, many foreign artists who experimented with emerging trends responded likewise to the social upheavals of the late 1960s, such as the May 1968 protests in Paris and resistance to US involvement in Vietnam, complicating the correlation between geographic origins and ideology.

Just as it is necessary to dispense with totalizing ideologybased polarities between art from Latin America and art from the United States and Europe, more attention must be paid to the specificity of critiques of Latin American artists and critics. This is especially the case in relation to Third Worldism, a Cold War-era political movement in the developing world that sought to promote national liberation and economic development. In terms of cultural production, the writings of Frantz Fanon proved to be the most influential throughout Latin America, especially in confronting legacies of colonialism. ${ }^{10}$ The Brazilian filmmaker Glauber Rocha reflected this influence in his manifesto "An Aesthetic of Hunger" (1965), which lauded the revolutionary power of an aesthetic of violence to inspire action and effect transformation. ${ }^{11}$ The implications of these theories for the visual arts can be seen in Artur Barrio's "Manifesto" (1970). Here Barrio advocated for a "Third World aesthetic" through the use of "perishable, cheap materials" to "cast his work in confrontation" with economic hierarchies. ${ }^{12}$

While rejecting neo-imperialism, Brazilian artists nevertheless saw themselves as heirs to the international modernist tradition. Indeed, it was because of this shared interest in European avant-garde movements that Brazilian artists can be seen as having a parallel relationship to those artists in North America and Europe who likewise revived aspects of the earlier twentiethcentury vanguard projects. In considering how Brazilian artists and critics of the late 1960s and early 1970s explored their relationship to art produced in artistic "centres," I will argue that Brazilian art at this time, far from being conceived in isolation, at once informed and was informed by art produced in such "centres." Using two exhibitions as case studies, I will argue that these artists updated Andrade's strategies to explore their own relationships to international movements in a time of increased mobility, simultaneously allowing for political and economic critique that responded to local conditions. Indeed, aided by the flexibility afforded by new media and alternative modes of dissemination, many Brazilian artists exhibited in international shows alongside participants from other countries. Most notably, curator Kynaston McShine included several of these artists in Information, an early exhibition of conceptualism at New York's Museum of Modern Art in the summer of 1970. This exhibition demonstrated what most scholarly literature has since ignored - that the development of trends such as conceptualism was a dialogue whereby artists from North America and Europe were concurrently exposed to Brazilian art as well as vice versa.

\section{Salão da Bússola}

The watershed exhibition Salão da Bússola (Salon of the Compass) took place between 5 November and 14 December 1969 at the Museu de Arte Moderna-Rio de Janeiro. The advertising firm Aroldo Araújo Propaganda sponsored the Salão to celebrate the company's fifth anniversary and to promote advancements in communications theories and the use of industrial materials in the visual arts. The exhibition's subtitle, "Comunicação e Desafio" ("Communication and Challenge"), reflected such ideals. Araújo offered, in addition to the standard acquisition prizes, a research prize that would encourage the integration of industry and the arts through internships in various industrial fields that allowed artists to work with plastic and synthetic fibres. ${ }^{13}$ In line with the firm's institutional mission, the organizers also encouraged research in the communications fields, particularly following the tenets of Marshall McLuhan, whose influential book The Medium is the Massage was published in Portuguese that year. ${ }^{14}$ As touted by the show's promotional material,

What Aroldo Araújo Propaganda wants to show with the evidence of the displayed works is that folklore and technology can coexist. The craftsman with the purity and spontaneity of his creations and the manipulator of cybernetic data are two useful components of the social organism in which they act. $^{15}$

The workshops that accompanied the exhibition emphasized these goals. Notable among them was "Creation and Communication in the Society of the Masses," given by the poet Décio Pignatari, a co-founder with Augusto and Haroldo do Campos of the Concrete poetry movement and the translator of McLuhan's Understanding Media into Portuguese. ${ }^{16}$ These workshops also demonstrated the international orientation of the exhibition: the participants in "The Integration of the Artist within Technology” were Mário Pedrosa from Brazil, Jorge Romero 
BRODBECK | The Salão da Bússola (1969) and Do Corpo à Terra (1970)

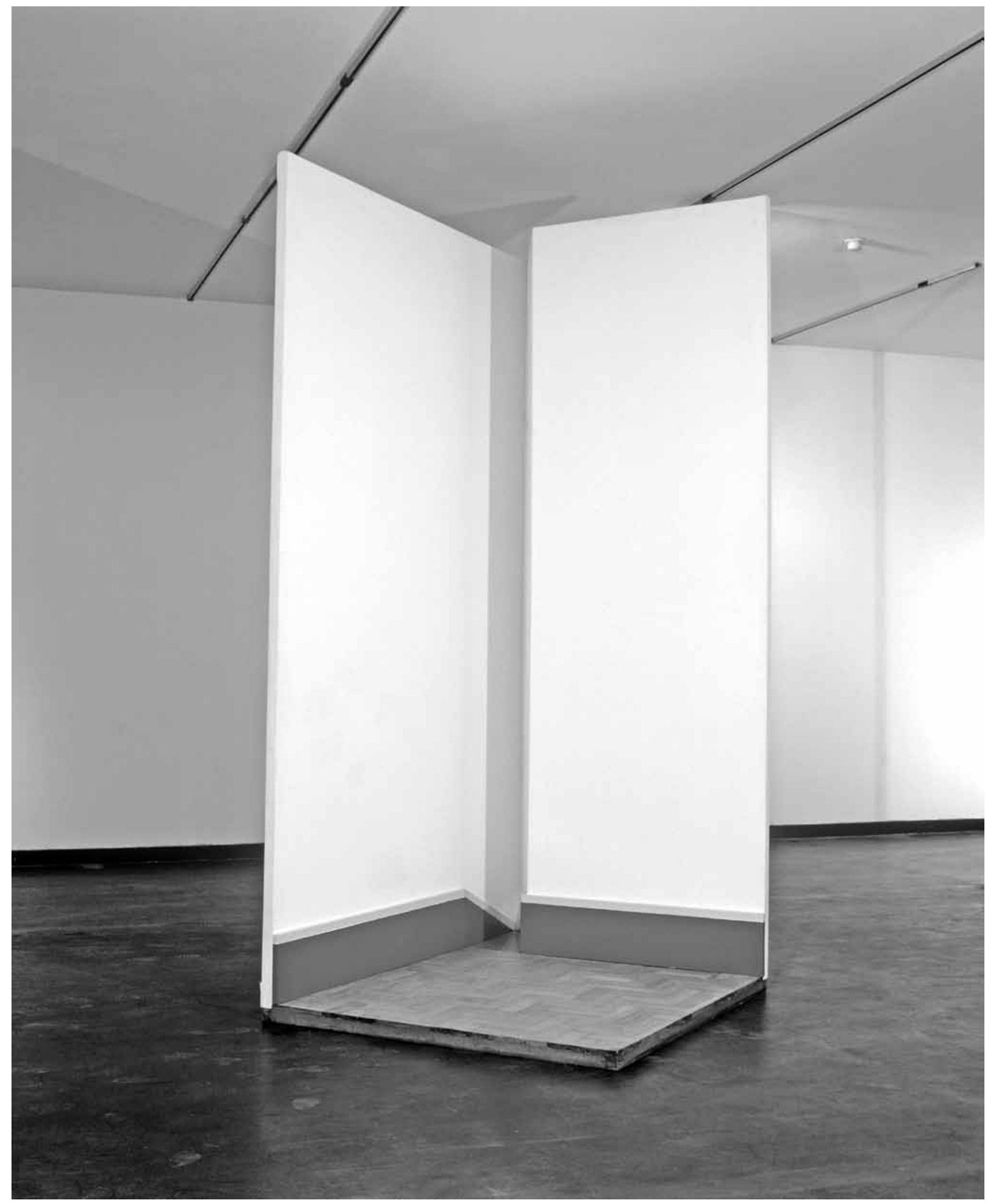

Figure I. Cildo Meireles, Espaços Virtuais (Virtual Spaces), from Cantos (Corners) series, 1967-68. Wood, canvas, paint, woodblock, flooring, $301.5 \times$ $185 \times 135 \mathrm{~cm}$. Rio de Janeiro, Museu de Arte Moderna (Photo: Vicente de Mello). 
RACAR XXXVIII | Number 2 | 2013

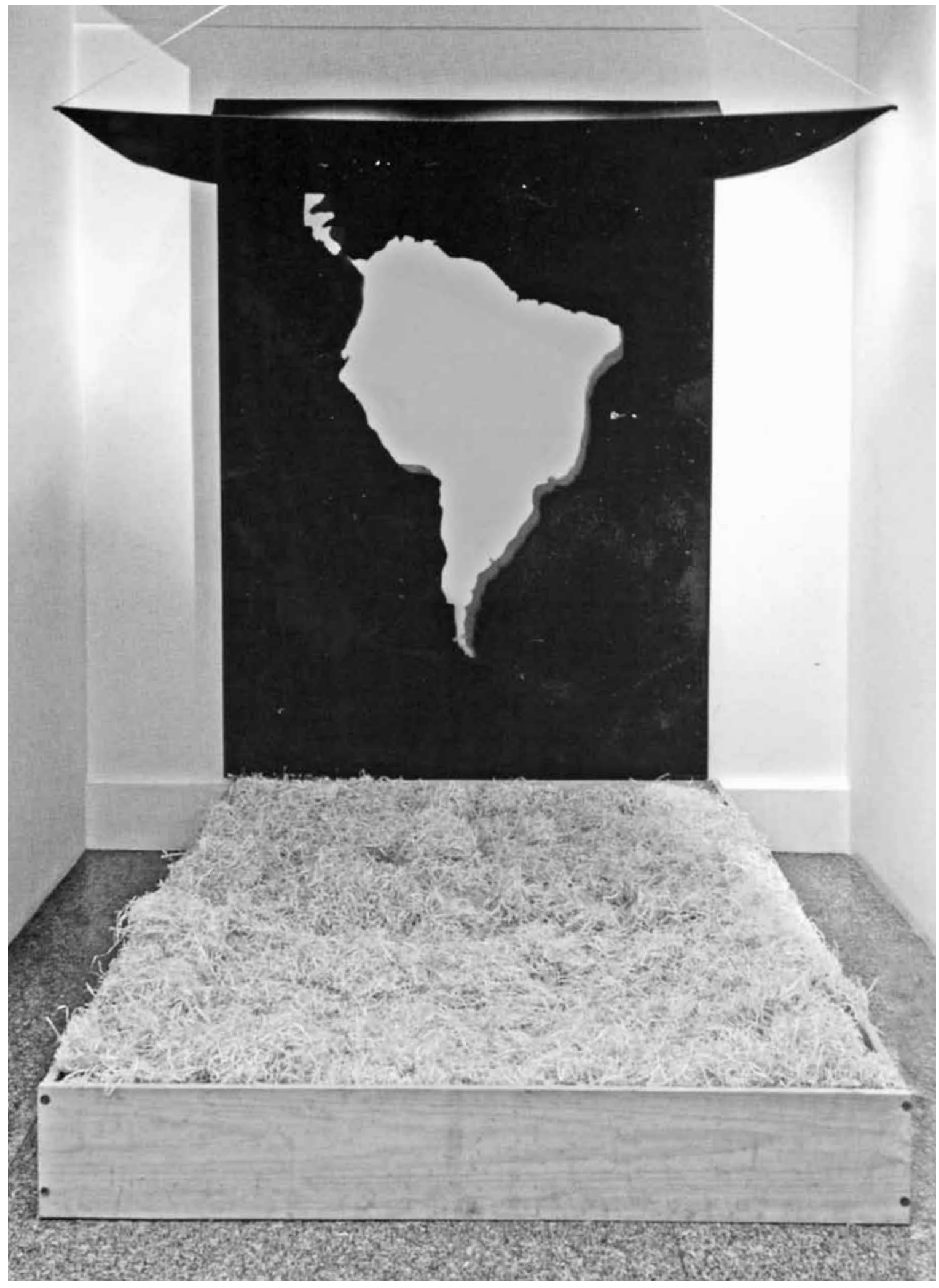

Figure 2. Antonio Manuel, Soy Loco por ti (I Am Crazy for You), 1969. Wood, cloth, plastic, grass, rope. Collection of the artist (Photo: Romulo Fialdini). 
Brest from Argentina, and Pierre Restany from France. Pedrosa, an influential critic who played a vital role in the development of Neoconcretism in Rio, wrote on happenings in Brazil. Romero Brest, who had been a juror at Documenta $I V$ in Kassel the previous year, was the director of the Instituto Torcuato Di Tella (ITDT), which advocated for Argentine art at home and abroad, often with connections to pop art and happenings. Restany was responsible for promoting the Nouveaux réalistes, a group of French artists who shared affinities with the Brazilian New Figuration tradition, a loosely defined movement of artists who returned to the figure, often incorporating social critique and humour into their kitsch representations of Brazilian life. He would become an active participant in the Brazilian art scene, contributing to exhibition catalogues, participating in museum debates, and even embarking on an artistic voyage with Sepp Baendereck and Frans Krajcberg down the Rio Negro in 1978.17

The presence of these international figures, however, also signalled a divergence from the intended themes of the exhibition. In the fall of 1969, Pedrosa and Restany joined forces to spearhead an international boycott of the São Paulo Biennial in protest of the military police's decision earlier that year to shut down an exhibition out of which the Brazilian delegation to the Paris Biennial would have been selected. This incited artists to send their works to the Salâo instead, 18 even though they had little to do with the exhibition's stated goals. They at once radicalized the bodily and "anti-art" qualities of Neoconcretism and rejected a strictly national allegiance.

Consider Cildo Meireles's Nowhere Is My Home (1969; fig. 1), for which he won the grand prize, a travel scholarship to London and New York. Part of the Cantos (Corners) series, this sculptural environment comprised sheets of wood and plaster painted to mimic the corner of a room, complete with a parquet floor. A noticeable misalignment between the two walls created a surreal space beyond the corner. ${ }^{19}$ The work represents an extension of the Neoconcretists' interest in perception and phenomenology, but Meireles's choice of the evocative English title Nowhere Is My Home suggests a rootlessness. It was intended as a pun on the conceptual painting series by contemporary Antonio Dias, Anywhere Is My Land. ${ }^{20}$ Reflecting its title, the domestic nature of Cantos and the ultimate impossibility of penetrating the closed space lent the work metaphoric resonances during a time in which artists felt it ever more impossible to create freely in Brazil. Indeed, both Dias and Meireles would live in exile, the latter relocating to New York from 1971 to 1973.

Similarly, Antonio Manuel exhibited a neo-figurative work, Soy Loco por ti (I Am Crazy for You; fig. 2), that resembled both a rejection of nationalism and a socio-political critique. The Spanish title, borrowed from a song recorded by Caetano Veloso in 1968,21 reflects the piece's continental connections: the work is composed of a red map of South America painted on a black background, which was then covered with a black sheet and positioned above a bed of grass. Viewers could lift the sheet with a dangling cord to reveal the map. Although the work had ludic connotations, it nevertheless proved to be controversial.22 Amidst claims that the black covering cloth and the red map of South America referred respectively to the anarchist and communist flags, the exhibition sponsors debated whether or not to remove the work. As a safeguard against any potential backlash from the military censors, they screened it for offensive content through an army general and a Catholic priest. Manuel, who felt uneasy with the political climate in Brazil, proposed to give up the work in exchange for a round-trip ticket to Paris or London, where Oiticica had been living. Ultimately it was accepted into the exhibition and won a top prize, and Manuel stayed in Rio.

Manuel's willingness to exchange his work for travel abroad can be interpreted as a sign of the frustration felt by the artist living with the constant threat of censorship of his works, which indeed had also been targeted in the 1969 pre-Paris Biennial shutdown. By including a sheet that serves to veil the map, Manuel parodied the very act of censorship. Moreover, as scholars have pointed out, Manuel's work also addressed US neoimperialism in much the same manner as the song that gave the work its name. ${ }^{23}$ This can be seen in the artist's use of so-called poor materials (the grass bed, for instance), which was formally indebted to the Neoconcretist tradition. Manuel recalls: "The exhibition lasted two months, so the grass bed started to get rotten and exhale a bad odor, which, for me, made sense: it was Latin America itself exhaling its decomposition."24

The powerful resonances of perishable materials were also exploited in Artur Barrio's contribution to the exhibition, Situação... ORHHH... 5.000... T.E... EM... N.Y... City... 1969 (Situation... ORHHH... 5,000... B.B... IN.. N.Y.. City... 1969, 1969; fig. 3). This work was the first in his Situaçâo (Situation) series, in which Barrio dumped burlap sacks filled with abject and often bloody materials (what he called "bloody bundles") in the museums, streets, and waterways of major Brazilian cities. In this first Situação, Barrio placed provisional bundles composed of newspaper, aluminum foam, and raw meat in the museum's gallery. He then invited spectators to throw their garbage into the bundles and even to scribble curse words on them. Viewers were also encouraged to discard money along with their garbage, a critique of the nation's monetary policy that would be echoed in Meireles's Inserçöes em Circuitos Ideologicos (Insertions into Ideological Circuits; 1970-75). 25 The reference to New York in the work's title tellingly points to another centre of global economic power.

After exhibiting his bundles for one month, Barrio moved them to the sculpture garden, placing them on the concrete pedestals reserved for "high art." This move into public space 


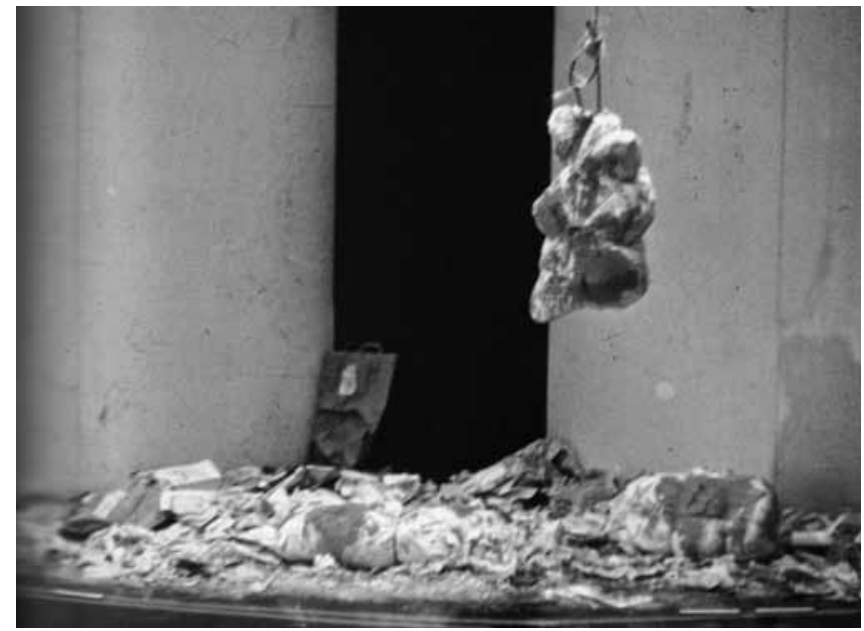

Figure 3. Artur Barrio, Situação... ORHHH...5.000... T.E... EM... N.Y.. City...1969 (Situation... ORHHH... 5,000 . . B.B...IN... N.Y...City... 1969), 1969. Installation view at Museu de Arte Moderna-Rio de Janeiro. Paper bag with newspapers, aluminum foil, bag of cement, garbage. São Paulo, Galeria Millan (Photo: César Carneiro).

provoked the military police, who, after demanding and receiving confirmation that the bundles belonged to the museum, nonetheless destroyed them. A more explicit exploration of the relationship between art and landscape can be seen in Territórios (Territories), a pioneering work executed by Luciano Gusmão, Dilton Araújo, and Lotus Lobo. For this initial version of the piece, which they originally wanted to perform in the museum's sculpture garden, the artists placed plastic, acrylic, and aluminum sheets in the vegetation of the Aterro do Flamengo, Rio's largest park. The wind was so strong that the work was destroyed. ${ }^{26}$ I will return to Territórios below; here one need only note how it exemplifies a more explicit dialogue with emergent "post-studio" practices such as land art in much the same manner as Barrio’s Situação series.

Even work that explored regional concerns such as an interest in Third Worldism was recognized by critics for its resonance with contemporary international practices. Writing in the Jornal do Comércio, Thomas Cohn commented on the parallel use of trash by Brazilian artists such as Barrio and Guilherme Magalhães Vaz and the British artist Barry Flanagan, and he likened Meireles's work delineating forms with cords to the work of Fred Sandback and Jan Dibbets. ${ }^{27}$ Cohn, who would later become a prominent gallerist, was at this moment just beginning to build his collection, travelling frequently to North America and Europe to see work that would inform his own acquisitions. ${ }^{28}$ By challenging the highly localized nature of the art market in Brazil, he played a key role in contextualizing Brazilian art among such international figures.
The most significant result of the critical reception, however, was to shift the debate away from the original goals of the exhibition's organizers. In his review in the Correio de Manhä, the journalist and critic Jayme Maurício commented that for all the talk of cybernetic qualities in the promotional material, a majority of the works sharply diverged from this aesthetic, suggesting a confrontation between primitive man and machine along the lines of Macunaima. ${ }^{29}$ The modernist novel by Mário de Andrade (1928) referenced here had recently been adapted for film by the director Joaquim Pedro de Andrade, who had updated it for late capitalism and added a layer of satire clearly aimed at the country's military dictatorship. 30 Walmir Ayala concluded in a review in the Jornal do Brasil that "The marriage of industry and art utterly failed, the artists being more interested in arte povera and the detritus of the underdeveloped world than in industrial products like those likely promoted by Araújo." 31

Ayala's statement framed the Salão in terms of both its local and international contexts, but his specific reference to arte povera requires close consideration. The critic Germano Celant coined this term to characterize the work of several Northern Italian artists who utilized precarious or organic materials. While for Celant, the work of these artists counteracted what he saw as the prevailing complacency of post-war Italian society by resisting commodification, the artists themselves were largely apolitical. ${ }^{32}$ Brazilian artists used similar poor materials to very different ends from those of their Italian colleagues, and at times resisted this affiliation. Barrio, for example, denied any intersection between the Situaçoes and contemporary foreign trends; "the use of precarious/momentary materials in my work," he wrote, "has NOTHING to do with Arte Povera."33 Such a strong disavowal was most likely ideologically motivated. This had certainly been the case with Oiticica, as evidenced by a 1968 letter to Lygia Clark:

Italian arte povera is made with more or less advanced means, it is the sublimation of poverty, but in an anecdotal, visual way, purposely poor but very rich. Indeed, it is the assimilation of the remains of an oppressive civilization and its transformation into consumption, the capitalization of the idea of poverty. For us it seems that the economy of elements is tied directly to the idea of structure. ${ }^{34}$

Oiticica's critique is at the heart of the theories of Third Worldism as embraced by artists such as Barrio. Indeed, as scholars have pointed out, the "povera" in arte povera was never meant to communicate actual poverty, but rather "poor means," and the misreadings that often flavoured the movement's reception understandably displeased those artists who sought to engage with the socio-economic reality of the developing world in their art. 35 
Ironically, it was exactly these ideological resonances that drew Kynaston McShine's interest. The curator had visited the Salâo da Bússola on a research trip to Rio, and based on what he saw there, he invited Meireles, Barrio, and Vaz to exhibit with Oiticica in Information. It was not just the formal affinities to international trends that McShine appreciated in their work. In his essay for the exhibition catalogue, he emphasized the pervasive environment of political instability that shaped art in both North and South America at the time:

The material presented by the artists is considerably varied, and also spirited, if not rebellious - which is not very surprising, considering the general social, political and economic crises that are almost universal phenomena of 1970. If you are an artist in Brazil, you know of at least one friend who is being tortured; if you are one in Argentina, you probably have a neighbor who has been in jail for having long hair, or for not being "dressed" properly; and if you are living in the United States, you fear that you will be shot at, either in the universities, in your bed, or more formally in Indochina. ${ }^{36}$

McShine appreciated the South American artists as exemplary in their incorporation of the larger social and political context that gave meaning to new forms of art making. This created a contradictory situation whereby some Brazilian artists tried to distance themselves from artists working in the artistic "centres" at the very moment their work became known for introducing socio-political critiques there. The work of the Brazilian artists explored here must be understood, then, as a continuum in terms of their interest in and resistance to international trends. This convergence in their art of the unique issues facing the underdeveloped world and an affinity to arte povera and land art from North America and Europe is most apparent in Do Corpo à Terra, the exhibition to which I will turn next.

\section{Do Corpo à Terra}

Do Corpo à Terra (From Body to Earth), an outdoor exhibition held on 17-21 April 1970 in Belo Horizonte, incorporated the formal vocabulary introduced in the Saláo da Bússola with the surrounding landscape. Concurrent with Objeto e Participaçâo (Object and Participation), a group exhibition organized by Mari'Stella Tristão at Belo Horizonte's newly inaugurated Palácio das Artes, Do Corpo à Terra was organized by Frederico Morais at the nearby Parque Municipal. It presented both a radicalization of the phenomenological experiments exhibited by Manuel and Meireles in the Salão da Bússola and a fulfillment of the unrealized potential of Territórios for land art. Indeed, as the exhibition's title made clear, landscape intervention and corporeal performance were ultimately linked in Do Corpo à Terra.

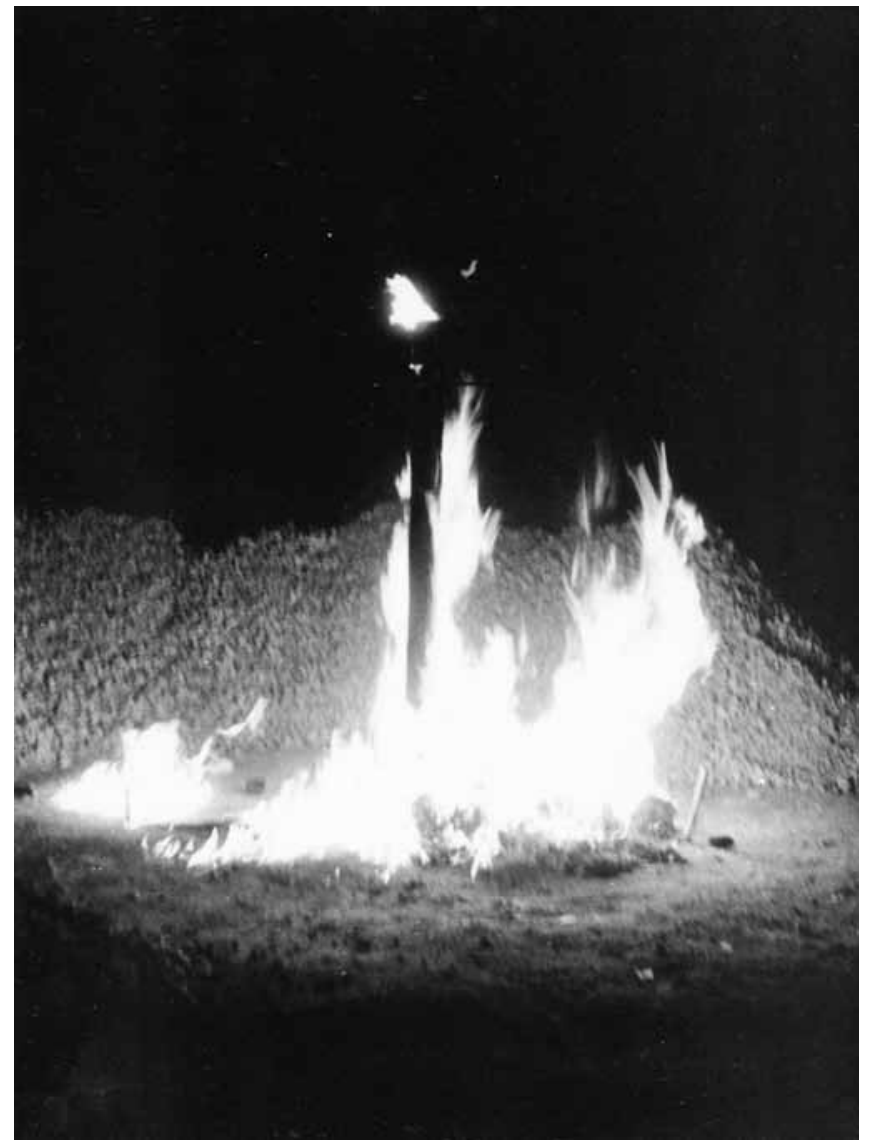

Figure 4. Cildo Meireles, Tiradentes: Totem-Monumento ao Preso Político (Tiradentes: Totem-Monument to the Political Prisoner), 1970. Wooden pole, white cloth, thermometer, ten live chickens, gasoline, fire (Photo: Luiz Alponsus Guimarães).

Meireles's Tiradentes: Totem-Monumento ao Preso Politico (Tiradentes: Totem-Monument to the Political Prisoner, 1970; fig. 4) is a case in point. This violent action, in which ten live chickens were doused in lighter fluid and burned alive during the exhibition's opening, constituted one of the most shocking protests against the conditions of dictatorship. By commemorating the execution of Joaquim da Silva Xavier (nicknamed Tiradentes, or "teeth puller") by the Portuguese colonizers in 1792, Meireles drew a clear parallel between the current political situation and the suppression of the fight for independence under colonial rule. His timing was apt, for the state of Minas Gerais paid tribute to the rebel dentist during the very week in which the exhibition took place. ${ }^{37}$ Although Meireles claimed that his works were not explicitly political, he later acknowledged that "they may become political at certain moments, or under certain circumstances-regardless of my will."38 Meireles's use of chickens in lieu of a human body mediated his 


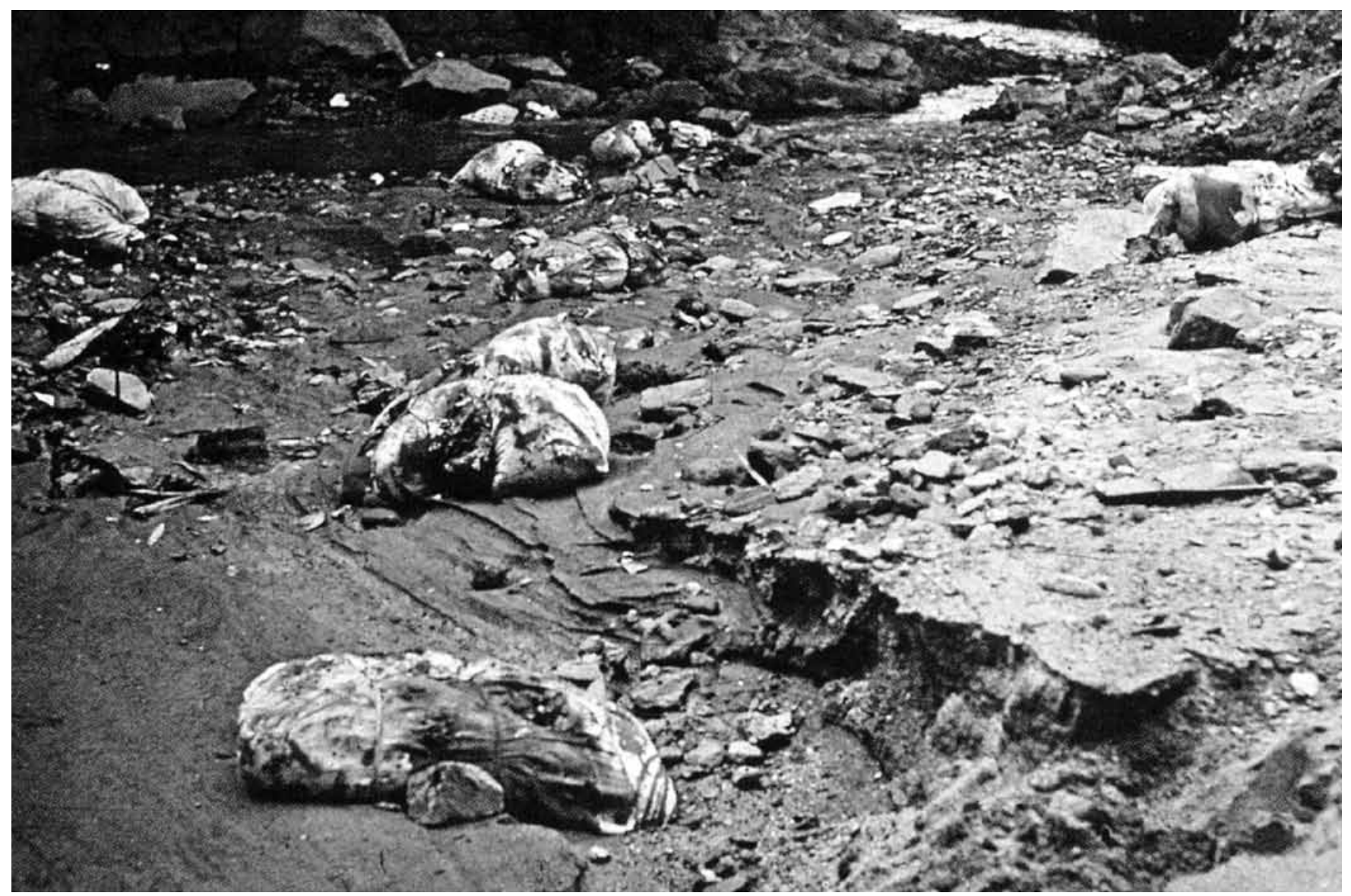

Figure 5. Artur Barrio, Situação.......T/T, I....... (Situation...... T/T, I ......), I970. Blood, meat, bones, clay, foam rubber, cloth, bags. Minas Gerais, Inhotim Centro de Arte Contemporânea (Photo: César Carneiro).

mimicking of state-sponsored crimes to put into high relief the violent suppression that had again befallen Brazil.

The political implications of this work have been the subject of much discussion, yet it is seldom remarked that elements of Tiradentes also suggest an affinity with "post-studio" art: Meireles submitted organic materials to a natural element (fire), but to horrific effect. While arte povera artists such as Janis Kounellis also used live animals in some of their work, none would do so in such a violent manner. ${ }^{39}$ One way to account for this is the distinctive use of metaphor that characterized other works in the exhibition, which allowed artists to comment on the offenses committed by the dictatorship. 40

For instance, metaphor is clearly at work in Barrio's contribution, Situação......T/T,1...... (1970; fig. 5). For this third Situação, the artist literalized the exhibition's title by creating a surrogate body from his own corporeal performance. He performed the first part of the situation, 14 Movimentos (14 Movements), inside the Palácio das Artes, where he prepared his "bloody bundles" for dispersion, this time giving them a corpse-like appearance by using blood, meat, bones, clay, foam rubber, and cloth. He concluded by dumping the bags into the park's open sewer, maintaining the connection between the museum and the outside world seen in the first Situação. While Barrio often incorporated a body of water into his work, the abject resonances of the sewer demonstrated his embracing of the base to counter the preciousness of the fine arts. An estimated five thousand people witnessed this performance, a remarkable feat given the elitist nature of Brazil's art world at the time. Not surprisingly, as a result of this exposure, Barrio's actions also attracted the attention of the police and firemen. In the work's final stage, Barrio went to the beach and scattered toilet paper on the rocks, letting it dissolve in the water. Although this Situação gives further evidence of Barrio's engagement of poor materials, it is its closer relationship to the landscape that is most important. Barrio submits his materials to a natural process of disintegration, and all that remains of this work is its 
photographic record, which Morais would later single out as a point of comparison with international contemporaries. 41

Though they did not attract as much controversy as the work of Meireles and Barrio, the exhibition's more subtle landscape interventions proved just as radical. The contributions by Oiticica, Gusmão, and Morais (who acted as both curator and artist) represent the development of a local form of Brazilian land art that has hitherto received very little attention. While land art (or earthworks) was not a codified movement, I will use the term to designate outdoor works that shared key characteristics with the other "post-studio" trends explored here.

Oiticica participated in Do Corpo à Terra in absentia, in the same transitional moment in which he had written "Brazil Diarrhea," his manifesto for universal experimentation. The artist had travelled to London for his Whitechapel Gallery exhibition in 1969, and upon his return passed through Rio only briefly before relocating to New York for much of the 1970s. Oiticica was more closely connected to the international art scene than the other participants, and his contribution, Trilha de Açucar (Trail of Sugar, 1970; fig. 6), was thus the work most directly impacted by travel and exchange. Oiticica enlisted the help of a friend from the United States, Lee Jaffe, who poured sugar into a trench dug into a nearby mountain, the Serra do Curral. The trail was filmed to record its changing state over time. (The sugar was intended to entice ants, but the work was bulldozed before the ants could consume it.) This site, the only one located outside the Parque Municipal, was chosen on account of the rich red colour of the soil, a by-product of the region's mining industry. This choice of location suggests metaphoric resonances that are echoed in the use of sugar, which as a substance imported by Portuguese colonizers and harvested through African slave labour has a distinctly transnational history. 42 Both formally and conceptually, Trilha de Açucar anticipates the Cosmococas, a 1973 series of installations by Oiticica and Neville d'Almeida. Attracted to the use of coca in Andean religious ceremonies, the artists utilized cocaine, a highly charged commodity similarly exploited in the West, as medium. 43

Oiticica subsequently denied any involvement with Trilha de Açucar. Morais tried to explain this disavowal by suggesting that Oiticica was trying to distance himself from the minor controversy created by this wasteful expenditure of sugar when many Brazilians had to do without. In any case, the friendship and collaboration between Oiticica and Jaffe is meaningful in and of itself in terms of the international network that Oiticica had developed. Jaffe was an important conduit between North American and Brazilian art, as he was active in both contexts and was instrumental in introducing the Brazilian artist to colleagues in New York when he relocated there. ${ }^{44}$ Oiticica was also in regular contact with McShine: his exhibition

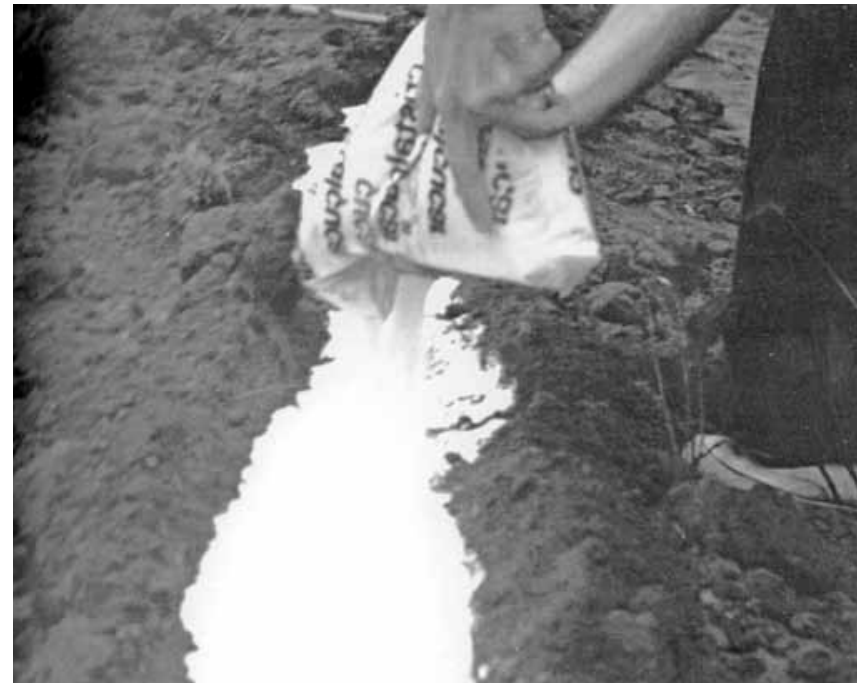

Figure 6. Lee Jaffe, Trilha de Açucar (Trail of Sugar), 1970. Sugar (Photo: Michel Rio Branco).

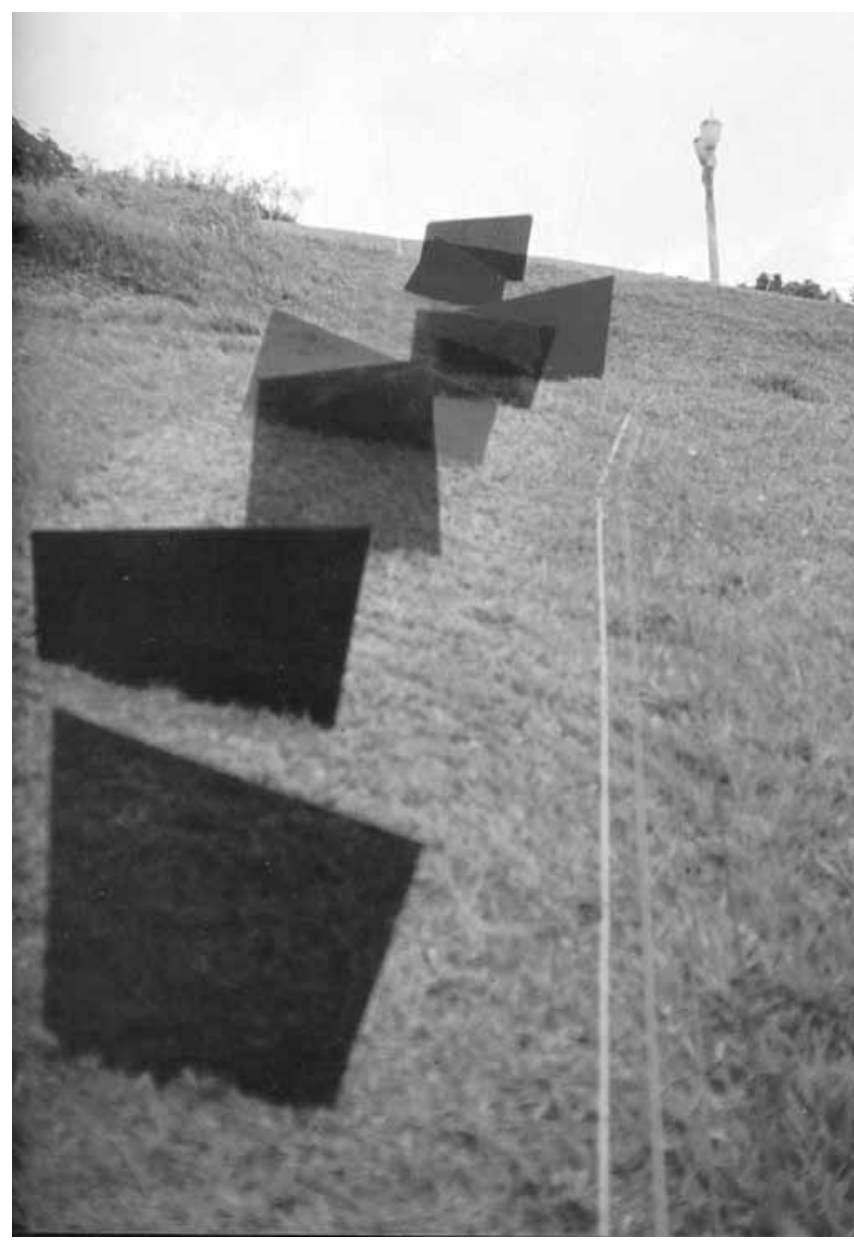

Figure 7. Dilton Araújo, Luciano Gusmão, Lotus Lobo, Territórios (Territories), 1969. Installation view at Museu de Arte da Pampulha. Plastic, acrylic, and aluminum sheets, cord, rocks (Photo: Lotus Lobo). 


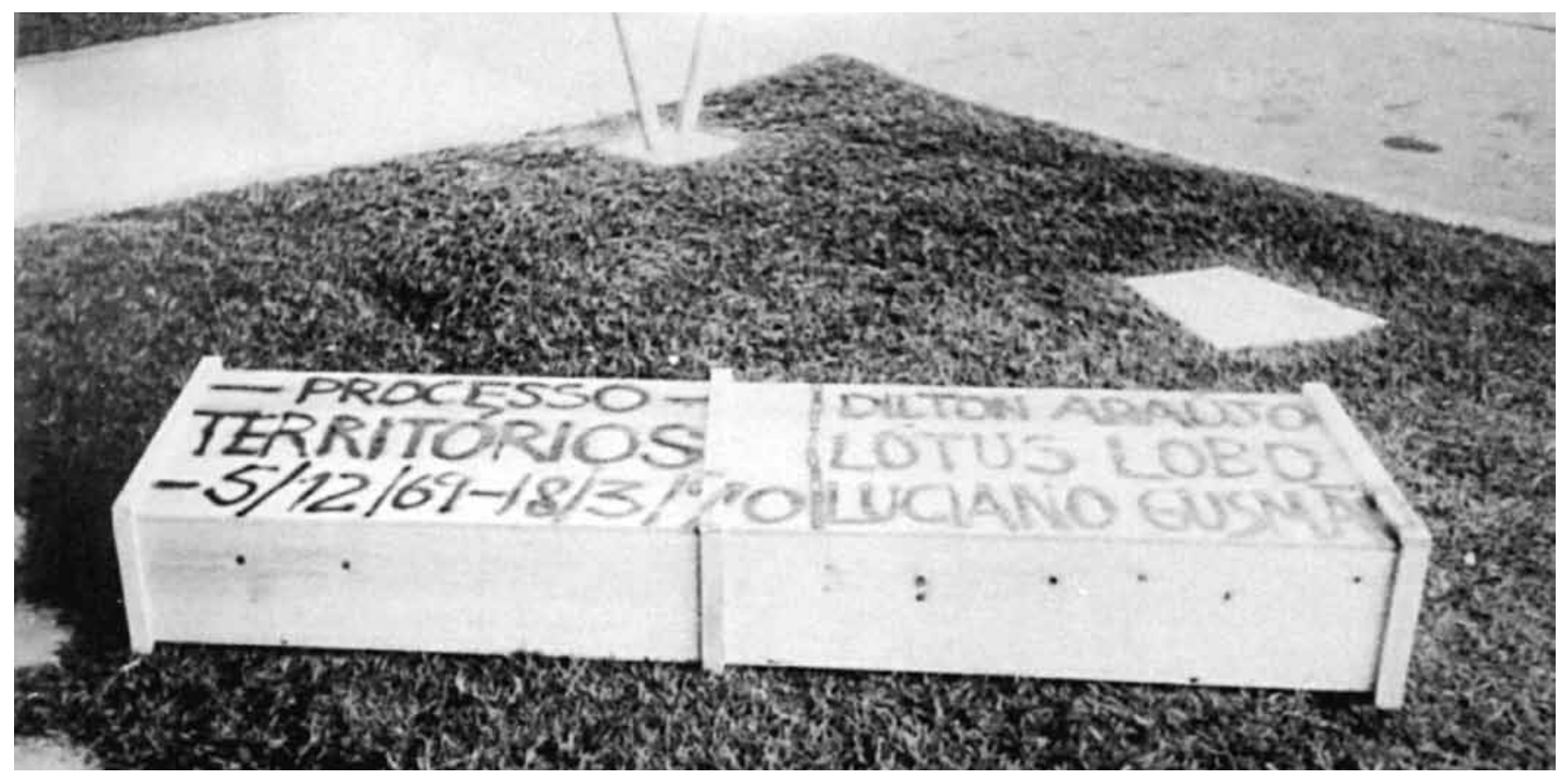

Figure 8. Dilton Araújo, Luciano Gusmão, Lotus Lobo, Territórios (Territories), 1969. Installation view at Parque Municipal, Belo Horizonte. Wooden box containing the remains of the installation at Museu de Arte da Pampulha (Photo: Lotus Lobo).

Information, which opened just months after Do Corpo à Terra, included many American and European land artists whose work was conceptually and formally similar to that of Oiticica. 45

If Oiticica had the closest connection with the work of artists from abroad, it was Gusmão who emerged as a pioneer of the Brazilian earthwork. His contribution to Do Corpo à Terra with the mineiro artists Lobo and Araújo was the culmination of a group project that was begun in 1968 and developed first at the Saläo da Buissola and then at the I National Salon of Contemporary Art in Pampulha. For this latter manifestation, the artists placed what they called tombstones-sheets of coloured plastic, acrylic, and aluminum-across the gardens of the Museu de Arte da Pampulha (fig. 7). It was the only work in the Pampulha Salon that incorporated the landscape. The artists maintained a connection to the indoor exhibition space by placing a rock in the gallery where the work would have been located; to it they attached one end of a string that led to at a tombstone outside. When visitors encountered the rock, they could follow the string to the window where the work would be visible in the gardens. Morais urged the artists to leave the elements of this installation out in the grass after the close of the Salon, eventually to be subsumed by nature, further heightening their likeness to tombstones. 46 Instead, once the objects had been warped by a few months of exposure to the elements, Gusmão and his col- laborators placed them in a large coffin-like box (fig. 8). They intended to donate the work to the museum in this form as a sort of relic, but their offer was refused. The artists exhibited the coffin-box in Do Corpo à Terra, an appropriate context: indeed, one of the tombstones was emblazoned with the words the body of the earth. The site shift suggests the artists' openness to the possibility of earthworks being re-staged in a new location.

This flexibility of site can be seen in Gusmão's solo work for Do Corpo à Terra. In Reflexōes (Reflections, 1970; fig. 9), the artist placed mirrors around the park and appropriated the objects they reflected as his work. This simple action could be recreated anywhere. In an interview, Gusmão stated that he wanted to manipulate the relationship between figure and ground so that the "the object is nature, and the image is the reflection." ${ }^{77}$ Contemporary artists such as Robert Smithson similarly explored the poetics of landscape reflection, as in Yucatán Mirror Displacements from 1969. However, Gusmáo’s specific mention of the figure-ground relationship points to a longtime preoccupation of Brazilian artists working in the Concrete and Neoconcrete traditions. This had been clearly articulated in Ferreira Gullar's 1959 "Teoria do náo-objeto" ("Theory of the Non-Object"), a manifesto of the Neoconcrete movement in which he proposed a solution to the figure-ground polarity that had stymied abstract artists in South America. In objective art, he wrote, 


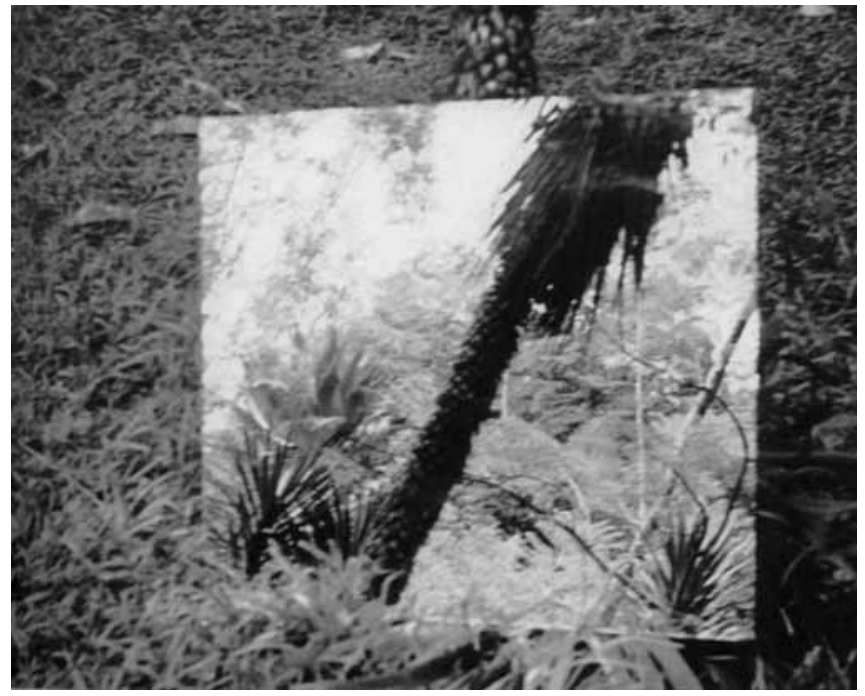

Figure 9. Luciano Gusmão, Reflexões (Reflections), 1970. Mirror (Photo: Frederico Morais).

that contradiction is insoluble since the background is in itself the same thing as perceiving; everything we perceive is on a background.... [However], in the non-object, since the problem of representation is avoided, the problem of the figure-background is avoided as well. The background, on which the non-object is perceived, is not a metaphorical background of abstract expression, but is real, actual spacethe world. 48

Gusmáo's literalization of the theory of the non-object is key to understanding many Brazilian earthworks, as it is one way to characterize the appropriation of the landscape as the "real space" against which these works would unfold.

Gusmão built on formal lessons learned from the Neoconcretists, but his work simultaneously paralleled reversibility, an idea put forth in land art, in that the work can easily be undone by removing the mirrors. This is explored in another solo work Gusmão contributed to the exhibition, Transpiraçâo (Transpiration, 1970; fig. 10). He laid a sheet of plastic on the park's lawn in order to trap the sweating of the grass. The work is reversible, as the condensation that is captured on the plastic sheet could be transferred back to the grass. In this way, Transpiraçâo parallels works by artists such as Hans Haacke, whose Condensation Cube (1963-65) similarly captured environmental effects, albeit with a more explicit relationship to the gallery setting. ${ }^{49}$ Haacke's explorations of biological systems were done, he stated, with "the explicit intention of having their components physically communicate with each other, and the whole communicate physically with the environment." 50 As Gusmão was trained as a scientist, such interests would very much intersect with his own. ${ }^{51}$

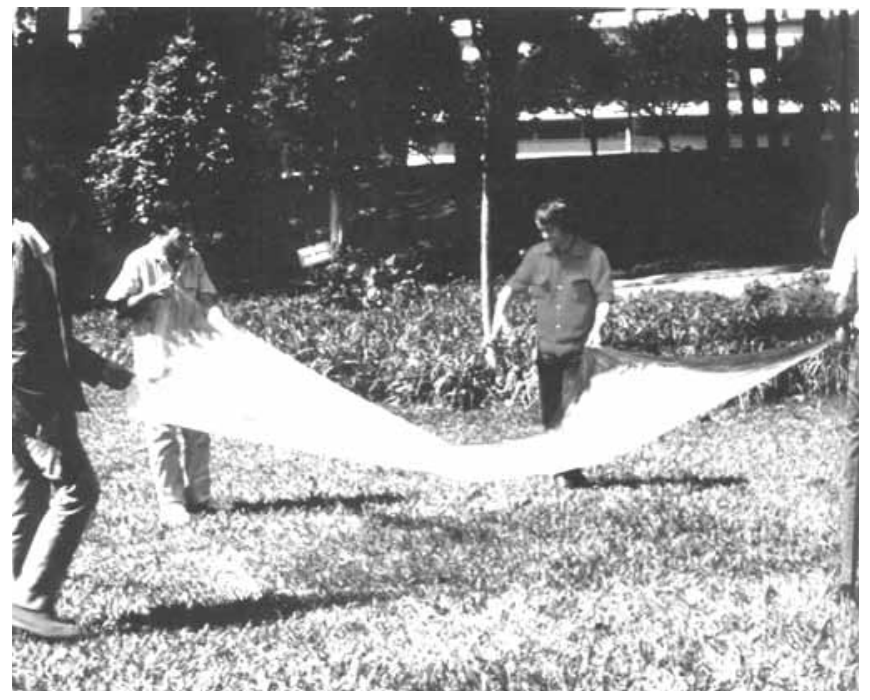

Figure 10. Luciano Gusmão, Transpiração (Transpiration), 1970. Plastic sheet (Photo: Frederico Morais).

Resonances between Gusmão and international contemporaries were discussed at length in his correspondence with Morais during the creation of Territórios. Their letters elucidate their understanding of land art, as well as the genealogy that Morais delineated for Brazilian artists participating in that vein. In a letter from February 1970, Morais linked Gusmão's work to that of like-minded artists from both Brazil and abroad, including Walter de Maria, Dennis Oppenheim, Robert Morris, Dibbets, Meireles, Mario Merz, Clark, Vaz, and Oiticica. He wrote,

But returning to the problem of nature. Every movement that has emerged in the past years in the United States and Europe and Brazil has some pioneering characteristics of the "post-studio" generation (Nowhere Is My Home is the title of one of the first works by Cildo Meireles, Free Continent is the name of a series of conceptual paintings by Antonio Dias), of arte povera, and of microemotive, or the "earthworks" movement. 52

Here Morais singled out Live in Your Head: When Attitudes Become Form as representative of this new direction; it displayed tendencies at which Brazilian artists had often arrived independently. 53 Artists such as Long and Dibbets had been included in the exhibition, and the latter's definition of earthworks was reproduced by Morais in this same letter: "Dibbets," he wrote, "said quite rightly that 'the work of art is a photo of the work, realized in the earth, on ice, or in the countryside... that once made can be unmade, transforming itself into nature. Photographed, anyone can reproduce my work.'"54 This definition certainly speaks to Gusmáo's experiments in reversibility 


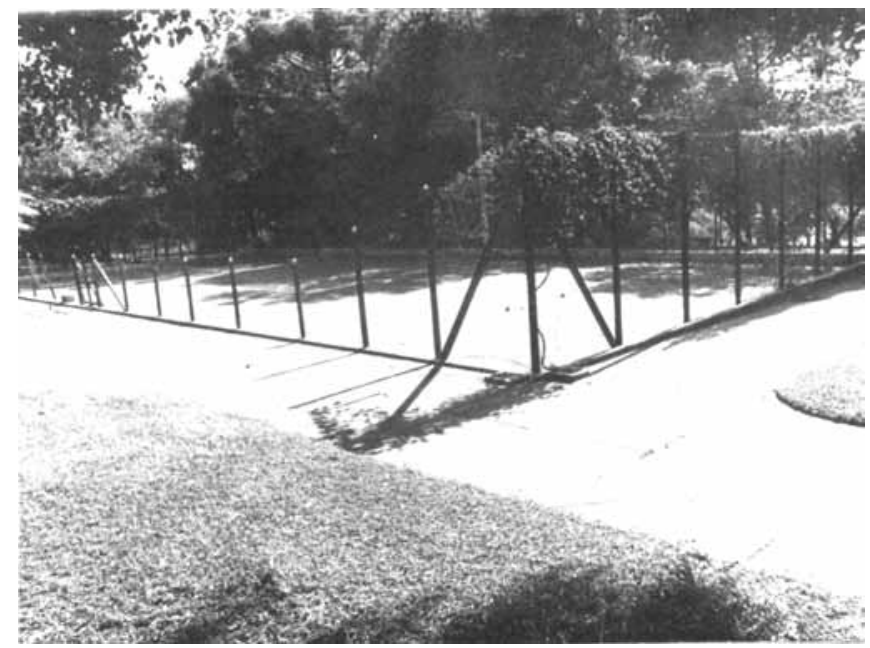

Figure II. Frederico Morais, 13. HOMENAGEM A MALEVITCH (I3. HOMAGE TO MALEVITCH), from Quinze Lições sobre Arte e História da Arte-Apropriações, Homenagens e Equações (Fifteen Lessons on Art and Art History-Appropriations, Homages, and Equations) series, 1970. Photomontage (Photo: Frederico Morais).

and site flexibility, and also to the philosophy of his Brazilian colleagues who designated the photographic reproduction as art in lieu of the actual art object.

The tension between site specificity and site flexibility ultimately points to the relationship between space and place as explored in these works. Artists from the highly diverse Latin American region have historically been mobile, a condition that poses challenges to geographically bound identities. Various theorists have responded by suggesting new ways of discussing Latin American art. Ramírez, in her 2000 exhibition Heterotopias, proposed studying it from the "no-place." 55 Maria Clara Bernal has suggested "appropriating from different places the elements to build a new space that has little to do with geographic location" and speaks of a "non-spatial place," thereby privileging community over geography. 56 There are larger implications for site-specific practices, especially as late capitalism created conditions of greater mobility and fragmentation on a global scale. To address these effects, Gilles Deleuze and Félix Guattari advocated for what they called rhyzomatic nomadism, in which the liberating effects of deterritorialization are celebrated. ${ }^{57}$ In her study of site specificity in art, Miwon Kwon characterized rhyzomatic nomadism as "displacing the strictures of place-bound identities with the fluidity of a migratory model... based...on the non-rational convergences forged by chance encounters and circumstances." 58 Such a model allows for artistic encounters outside the confines of geographic borders, facilitated by the increasing prominence of portable media at the onset of the 1970s and its easy distribution to exhibitions abroad.

\section{Conclusion}

In his work as critic and artist, Morais addressed both the specificity of the critiques posed by the works explored above and their implications in a world made smaller by globalization. Speaking with Francisco Bittencourt at the time of Do Corpo à Terra, he characterized Barrio and his contemporaries in ways that echoed Maurício's celebration of the confrontation between man and machine in his review of the Salâo da Bússola.59 Announcing the participants of Do Corpo à Terra as heirs to the 1922 Week of Modern Art, Morais proclaimed:

\begin{abstract}
We are the barbarians of a new race.... Our medium is not well-behaved acrylic, nor do we crave hygienic primary structures. What we make are celebrations, ritual sacrifices. Our instrument is our own body-against computers. Our handcrafts are mental. We use the head-against the heart. The inverse of "lasers"-imagination. And guts and sperm are necessary. Blood and fire purify. Our problem is ethicagainst aesthetic masturbation. ${ }^{60}$
\end{abstract}

Here Morais staked a claim for the defining qualities of the Brazilian neo-vanguard. He began by distinguishing the two veins of Brazilian art that formed his category of "NeoConstructivism"-New Figuration and Neoconcretism-from their American counterparts (the well-behaved acrylic and primary structures of pop and Minimalism); as demonstrated in the Salão da Bússola, these Brazilian artists pitted themselves against technologically advanced art by preferring the simple means of their own bodies and of detritus over expensive materials. Morais explained this renunciation of industrial materials as reflecting both the final stage of industrial capitalism and the larger trajectory of modern Western art, trash having been first introduced in the collages of Kurt Schwitters. Although Morais was mindful of the real economic disparities between the "centre" and the "periphery," he also acknowledged that in contemporary society, metropolises were becoming increasingly similar. Even Brazil was not a monolithic entity, he noted, in that cities such as São Paulo could exert economic imperialism in the same manner as centres of power in the Northern Hemisphere. He concluded thus:

Waste is above all a problem of large urban cities: São Paulo, New York, Tokyo, Milan, a socio-cultural problem, if not a moral one. Garbage is political violence, it is the death squad, it is torture, censorship, and hunger and all the other clichés, Brazilian or foreign. ${ }^{61}$

This statement implies that under globalization, even some of the distinct issues facing the Third World are comparable to those of the developed world. 


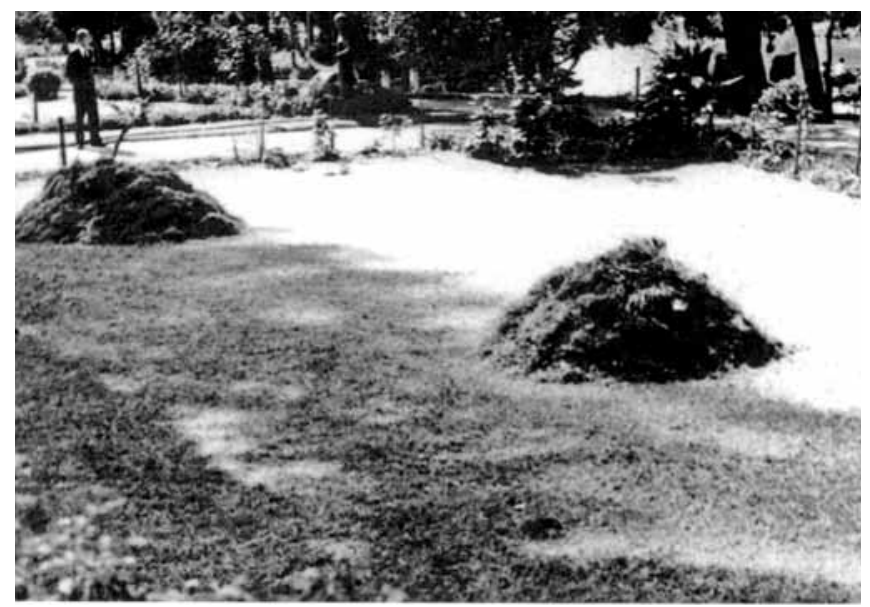

Figure 12. Frederico Morais, 12. CONTRA-ARTE/CONTRA-NATUREZA (12. AGAINST-ART/AGAINST NATURE) from Quinze Lições sobre Arte e História da Arte - Apropriações, Homenagens e Equações (Fifteen Lessons on Art and Art History_Appropriations, Homages, and Equations) series, 1970. Photomontage (Photo: Frederico Morais).

Morais's evocation of Schwitters suggests that it was the historic avant-garde rather than foreign contemporaries that informed his conception of the development of "anti-art" in Brazil. He articulated this best in his own montage Quinze Liçôes sobre Arte e História da Arte-Apropriaçôes, Homenagens e Equaçôes (Fifteen Lessons on Art and Art History-Appropriations, Homages, and Equations; 1970), executed for Do Corpo à Terra. The work comprised fifteen photographs of diverse sites throughout the Parque Municipal, with corresponding legends that were placed on placards in front of each site. Illuminating the legacy that Morais sought to delineate for contemporary Brazilian art, the placards created homages to the artists of the 1910s and 1920s who had previously sought to fuse art and life. For example, the legend for a fenced-off area entitled 13. HOMENAGEM A MALEVITCH (13. HOMAGE TO MALEVITCH; fig. 11) reads "the white world of the absence of objects," referencing the utopian goal of suprematism to annihilate the art object. However, as is visible behind the scaffolding, the world is neither white nor void of objects - it is the real lived space of the Parque Municipal. This legacy culminates in the development of "anti-art," as other captions read "Art doesn't leave traces" and "Against-art/ Against-nature-Where is art? Where is nature?" (fig. 12). In this installation, which echoed his writings at the time, Morais argued clearly that "post-studio" art evolved from the longer trajectory of Western art history, a tradition to which Brazilian artists were equal heirs.

Brazilian art of the late 1960s and early 1970s intersected with and diverged from international manifestations, but its shared roots in the historic avant-garde suggest an overall parallel development. It is clear that Brazilian art reflected domestic concerns both formal (the evolution of homegrown Neoconcretism and New Figuration) and ideological (the increasingly oppressive political and economic conditions exasperated by neoimperialism that led to an interest in Third Worldism). It has become increasingly apparent that dialogues between Brazilian and international figures were prevalent and were encouraged by Brazilian institutions such as the São Paulo Biennial and the privately sponsored Salão da Bússola. What has been less explored, and what this article has begun to address, is the manner in which such dialogues affected artistic production at this time. Affinities varied not according to exposure or proximity, but to the specific project of the artist. Consider the participants in Do Corpo à Terra: although Oiticica was most directly involved in the international artistic community, it was Gusmão, who spent his short artistic career in Belo Horizonte, whose work was most similar to land art produced in North America and Europe. Thus Morais's placement of the origins of such similarities with the historic avant-garde has emerged as the most convincing way to explain such parallel developments, for artists producing art in this vein responded to this legacy irrespective of their home country. The inclusion of Brazilian artists in Information proves that they were recognized at that historical moment as representative of current trends in mainstream artistic "centres," even if later curators and art historians would leave them out of the picture. However, this temporary lacuna should by no means be taken as a sign of the efficacy of their projects, and there is now immense interest in their work both in Brazil and abroad. As this article shows, Brazilian artists of the late 1960s and early 1970s effectively answered Andrade's call to create a universal experimentation, born of Brazil but walking in step with international art.

\section{Notes}

Unless otherwise indicated, translations are mine. The reviews of the Saláo da Bússola were accessed at the institutional archives of the Museu de Arte Moderna-Rio de Janeiro (MAM-RJ). These reviews were abstracted from the original periodicals with the page numbers omitted. I have supplied page numbers when I have been able to locate the original periodicals in other institutions.

1 Mari'Stella Tristão, “Da Semana Vanguarda (I)," Estado de Minas, 28 April 1970, 5.

2 I will use international here mainly to refer to cosmopolitan centres of cultural production in the United States and Europe; however, it is important to note the historic shifts occurring at this moment that opened the dialogue to many cities beyond traditional 
centres such as Paris and New York. While prior to this period, most Brazilian artists looked directly to Paris and loci of European abstraction like Ulm, by the time of Live in Your Head: When Attitudes Become Form (1969), they engaged the work of artists from countries such as the Netherlands, England, Canada, and Japan in addition to those from South America, above all Argentina.

3 Oswald de Andrade, "Manifesto Antropófago" (1928), reprinted in English in Carlos Basualdo, ed., Tropicália: A Revolution in Brazilian Culture (São Paulo, 2005), 205-07.

4 Hélio Oiticica, "Brasil Diarréa," (5-10 February 1970), reprinted in English in Hélio Oiticica (Rotterdam, 1992), 17-20.

5 "Anti-art" was the preferred term of Brazilian critics such as Mário Pedrosa and Frederico Morais.

6 Live in your Head: When Attitudes Become Form. Works, Concepts, Processes, Situations, Information (Bern and London, 1969).

7 Mari Carmen Ramírez, "Blueprint Circuits: Conceptual Art and Politics in Latin America," Latin American Artists of the Twentieth Century, ed. Waldo Rasmussen, Fatima Bercht, and Elizabeth Ferrer (New York, 1993), 156-67. This essay was republished as "Tactics for Thriving on Adversity: Conceptualism in Latin America, 1960-1980" in Global Conceptualism: Points of Origin, 1950s1980s, ed. Luis Camnitzer, Jane Farver, Rachel Weiss, László Beke (New York, 1999), 53-71. See also Luis Camnitzer, Conceptualism in Latin American Art: Didactics of Liberation (Austin, 2007).

8 Andrea Giunta has demonstrated this interplay of domestic politics and international exchange in the Argentine context in her Avant-Garde, Internationalism and Politics: Argentine Art in the 1960s (Durham, 2007).

9 See Claudia Calirman, Brazilian Art under Dictatorship: Antonio Manuel, Artur Barrio, and Cildo Meireles (Durham and London, 2012); Denise Carvalho Bergstrom, "Articulations and Interventionist Art: Negotiating the Production of Knowledge in Brazilian Culture,” Ph.D. diss., University of California, Davis, 2005; and Elena Shtromberg, "Conceptual Encounters: Art and Information in Brazil, 1968-1978," Ph.D. diss., University of California, Los Angeles, 2007.

10 Frantz Fanon, Les Damnés de la Terre (Paris, 1961) was perhaps the single most influential text in this regard. It was translated into Spanish in 1963 and into Portuguese in 1968.

11 Glauber Rocha, "An Aesthetic of Hunger," trans. Randal Johnson and Burnes Hollyman, in Brazilian Cinema, ed. Randal Johnson and Robert Stam (New York, 1995), 68-71; originally published as “A Estética da Fome," Revista da Civilização Brasileira (July 1965).

12 Artur Barrio, "Manifesto (1970)," reprinted in Vitoria Daniela Bousso, ed., Artur Barrio: a metáfora dos fluxos 2000/1968 (São Paulo, Rio de Janeiro, and Bahia, 2001), 136.

13 “Pesquisa e Comunição," Diário de Noticicas, 21 November 1969, institutional archives of MAM-RJ.

14 Marshall McLuhan with Quentin Fiore, The Medium is the Massage (New York, 1967); published in Brazil as O meio é a mensagem, trans. Ivan Pedro de Martins (Rio de Janeiro, 1969).

15 Promotional material found in the institutional archives of MAM-RJ.

16 Marshall McLuhan, Os meios de comunicação como extensôes do homem (Understanding Media), trans. Décio Pignatari (São Paulo, 1969).

17 The two Eastern European-born artists immigrated to Brazil at mid-century.

18 Indeed, the Salão da Bússola featured a series of lectures that situated it in the context of other international exhibitions, such as one featuring Dusan Roll, the founder of the International Biennial of Bratislava.

19 Nowhere Is My Home was the name given specifically to the iteration of the series for the Salão; this version no longer survives. The figure illustrated here is the prototype for the version exhibited there.

20 Cildo Meireles, interview with the author, Rio de Janeiro, 9 July 2012.

21 "Soy loco por ti, América" was composed by Gilberto Gil and José Carlos Capinan in 1966, but it was Veloso who first recorded it.

22 Antonio Manuel et al., Antonio Manuel: Entrevista a Lúcia Carneiro e Ileana Pradilla (Rio de Janeiro, 1999), n.p.

23 Christopher Dunn, Brutality Garden: Tropicália and the Emergence of a Brazilian Counterculture (Chapel Hill, 2001), 149.

24 Antonio Manuel, Entrevista a Lúcia Carneiro e Ileana Pradilla, n.p.

25 Not only does Meireles reappropriate currency for the purpose of critiquing foreign-imposed monetary policy by stamping "Yankees Go Home" onto bills from both Brazil and the United States, but in his "Zero Cruzeiro" project (1974-78), he creates his own currency in the denomination of zero, thereby emptying it of its ability to signify exchange value.

26 “Natureza Veneceu," Jornal do Comércio, 24 October 1969, 1, institutional archives of MAM-RJ.

27 Thomas Cohn, "O Salão da Bússola," Jornal do Commérico, 30 December 1969, institutional archives of MAM-RJ.

28 Thomas Cohn, telephone interview with the author, 15 March 2012.

29 Jayme Maurício, "Salão da Bússola: Cibernética ou Macunaíma?," Correio da Manhã, 18 November 1969, institutional archives of MAM-RJ.

30 The story follows the travails of Macunaíma, who was born to an elderly woman from the Amazon as a fully-grown man of African descent. Representing the trope of the ideal noble savage, he travels to the city, where he encounters modern technology for the first time.

31 Walmir Ayala, "Artes na semana," Jornal do Brasil, 21-22 December 1969, Section Caderno b, 4, institutional archives of MAM-RJ.

32 Elizabeth Mangini discusses the disengagement from politics of the Italian artists appropriated for arte povera in "Parallel Revolution: Elizabeth Mangini on Arte Povera," Artforum International 46, 3 (November 2007): 159-60, 162 
33 "In Relation to Aspects: Labels/Schools and Possibilities (1975)," reprinted in Busso, ed., Artur Barrio, 135.

34 Hélio Oiticica, letter to Lygia Clark, 15 October 1968, in Lygia Clark-Hélio Oiticica: Cartas, 1964-74, ed. Luciano Figueiredo (Rio de Janeiro, 1998), 54.

35 Thomas Crow, for example, has argued that arte povera more accurately reflects the economic abundance of Northern Italy where the movement originates. See The Rise of the Sixties: American and European Art in the Era of Dissent (New Haven, 1996).

36 Kynaston McShine, "Essay," Information (New York, 1970), 138.

37 "Minas faz homenagem a Tiradentes," Jornal do Brasil, 16 April 1970, Section 1, 7.

38 Cildo Meireles in conversation with Frederico Morais, 1 September 2008. Published in Tate Etc. 14 (Autumn 2008).

39 Kounellis exhibited live horses in his 1969 solo exhibition in Rome at L'Attico gallery organized by Fabio Sargentini.

40 Animal sacrifice also brings to mind candomblé, the Afro-Brazilian religion.

41 Letter from Morais to Luciano Gusmão, 4 February 1970, reprinted in Fabiola Moulin and Rute Assis, eds., Neovanguardas: Museu de Arte da Pampulha 50 anos (Belo Horizonte, 2008), 23-27.

42 Lee Jaffe, telephone interview with the author, 21 June 2011.

43 For a discussion of Oiticica's experimental filmmaking and Cosmococas, see Carlos Basualdo, Hélio Oiticica: quasi-cinemas (Ostfildern-Ruit, 2001).

44 Jaffe, telephone interview with the author, 21 June 2011.

45 Here we might consider A Line Made by Walking, a 1967 work by Richard Long, which has obvious formal affinities to Trilha de Açucar, without, however, its symbolic resonances.

46 Letter from Morais to Gusmão, 24.

47 Marília Andrés Ribeiro, Neovanguardas: Belo Horizonte, anos 60 (Belo Horizonte, 1997), 231.

48 Ferreira Gullar, "Diálogo sobre o não-objeto," Jornal do Brasil, 21 November 1960, Sunday supplement; reprinted in English in Mari Carmen Ramírez and Héctor Olea, eds., Inverted Utopias: Avant-Garde Art in Latin America (Houston, 2004), 521-22.

49 Letter from Morais to Gusmão.

50 Hans Haacke, cited on the occasion of his 1967 solo exhibition at the Hayden Gallery, Massachusetts Institute of Technology (Peter Mechsler, "Haacke to Exhibit Kinetic Art," The Tech, 7 October, 1967, 5); reproduced in Hans Haacke 1967 (Cambridge, 2011), $9-10$.

51 Frederico Morais, interview with the author, Rio de Janeiro, 6 April 2012.

52 Letter from Morais to Gusmão.

53 Letter from Morais to Gusmáo.

54 Jan Dibbets, cited in letter from Morais to Gusmão.

55 Mari Carmen Ramírez, Heterotopías. Medio Siglo Sin-Lugar: 19181968 (Madrid, 2000).
56 Maria Clara Bernal Bermudez, "Questions on Place and Space in Latin American Art," Latin Art (November 2005), http://www. latinart.com/ (consulted 7 December 2012).

57 Gilles Deleuze and Félix Guattari, Mille plateaux (Paris, 1980).

58 Miwon Kwon, One Place After Another: Site-Specific Art and Locational Identity (Cambridge, MA, 2002), 165.

59 Francisco Bittencourt, "A Geração Tranca-Ruas," Jornal do Brasil, Rio de Janeiro, 9 May 1970, Section Caderno b, 1.

60 Morais, quoted in Bittencourt, "A Geração Tranca-Ruas."

61 Morais, quoted in Bittencourt, "A Geração Tranca-Ruas." 